\title{
EFFECTS OF PROLONGED ADRENOCORTICAL STIMULATION ON PATIENTS WITH RHEUMATOID ARTHRITIS
}

\author{
BY \\ H. F. WEST \\ Sheffield Centre for the Investigation and Treatment of Rheumatic Diseases
}

(RECEIVED FOR PUBLICATION MAY 8, 1957)

The only practical means of maintaining a raised output of steroids from the adrenal cortex is by the daily intramuscular or subcutaneous injection of corticotropin in a medium that delays absorption. The effects produced by such therapy depend upon - the amount by which the daily output of steroids is raised above the starting level and the length of time that the raised level is maintained. The only practical means of measuring the output of the adrenal cortex is by assaying, in 24-hr specimens of urine, the metabolites of the principal hormone cortisol (hydrocortisone). The study reported here covers $4 \frac{1}{2}$ years, and is a follow-up of a previous study (West and Newns, 1955). For the first 18 months the metabolites of cortisol were assayed by the "17-ketogenic steroid" (17 KGS) method (Norymberski, Stubbs, and West, 1953) and since then they have been assayed by the "total 17-hydroxycorticosteroid" (17(OH)CS) method (Appleby, Gibson, Norymberski, and Stubbs, 1955). Both assays were developed at this Centre. The results of these two assays do not differ appreciably except in the rare disorders of the adrenal cortex. Consideration of the value and limitations of these assays will be referred to under the heading "Discussion" below but it can be stated at this point that a study of some 3,000 assays in conjunction with the clinical state of the patients concerned leaves no doubt that the anti-rheumatic effects produced by stimulating the adrenal cortex vary directly with the urinary output of $17 \mathrm{KGS}$ and $17(\mathrm{OH}) \mathrm{CS}$.

There have been many brief reports of the effects produced by corticotropin therapy and not a few describing undesirable effects, but rarely, if ever, have these reports included a statement of the level of adrenocortical stimulation achieved or of its duration. In view of the undesirable effects reported, this paper will take account of every

* Part-time Nuffield Research Fellow, University of Sheffield. patient suffering from rheumatoid arthritis that has been treated here with corticotropin during the last $4 \frac{1}{2}$ years.

\section{Material}

Patients.--These fell into two categories:

(A) 44 patients who had completed a short course of therapy ( 3 to 6 weeks), the therapy in no case having been withdrawn because of ineffectiveness or complications. This group included patients receiving adrenal restimulation after prolonged oral corticosteroid therapy and patients with acute exacerbations of the disease not thought to be in need of prolonged therapy.

Those in the second category provided opportunitie for the study of various preparations of corticotropin.

(B) 66 patients whose therapy either exceeds 3 months and continues to date or whose therapy has had to be withdrawn for one of the reasons to be stated.

42 of these patients ceased to receive therapy for the following reasons:

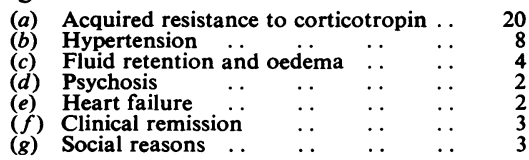

The circumstances of these 42 withdrawals will be referred to again below.

Most of these 66 patients were considered in need of prolonged therapy since their disease had been aggressive and disabling for many months. At this Centre approximately one in every twenty rheumatoid arthritis patients was selected for prolonged adrenal stimulation or oral corticosteroid therapy (the latter therapy mainly for the purpose of controlled trials). Many of the severe cases had been referred from other hospitals, so that the percentage of hormone-treated patients from the general rheumatoid population will have been less than 5 per cent. In choosing severely affected patients for prolonged adrenal stimulation therapy, some further selection was inevitable. For prolonged therapy, patients have to have sufficient intelligence and facility to give themselves (or be given by a close relative) daily injections of corticotropin. Complicating diseases, such 
as tuberculosis, chronic nephritis, and hypertension (save in two cases), excluded patients from this study.

Dosage.-For the last 4 years little corticotropin has been used other than Armour's High Purity Acthar Gel. This is an oxycellulose purified preparation. A dose large enough to raise the daily urinary output of $17 \mathrm{KGS}$ or $17(\mathrm{OH}) \mathrm{CS}$ to from 20 to $35 \mathrm{mg}$. was given daily by intramuscular injection. The level aimed at varied with the severity of the disease and the clinical response. Frequent urinary assays were made until a steady therapeutic level was achieved. Thereafter assays were performed at least every 4 weeks, unless a change in the batch number of the corticotropin or an alteration in the clinical state of the patient called for additional assays to check the degree of adrenal stimulation.

Follow-up and Records.-Patients were seen at least every 4 weeks after discharge from hospital and a record was made of the following:

Clinical state; weight; blood pressure; strength of grip; erythrocyte sedimentation rate; haemoglobin; packed cell volume; total white blood count; eosinophil count; 24-hr urinary excretion of $17 \mathrm{KGS}$ or $17(\mathrm{OH}) \mathrm{CS}$.

For 2 years estimations of serum albumin and globulin, fibrinogen, and cholesterol were made, but these were not continued as they were not providing any useful additional information (the serum cholesterol levels did not rise).

The total white blood cell counts, which were found to rise roughly in proportion to the level of adrenal stimulation, will not be referred to further. The eosinophil counts were too variable to be of interest or value after the initial period of adrenal stimulation.

\section{Findings}

(A) Short-Term Adrenocortical Stimulation (3 to 6 weeks) in 44 patients (Group A)

No patient failed to show evidence of adrenocortical stimulation after the intramuscular administration of a known potent preparation of corticotropin-provided they had not previously received corticotropin and acquired the ability to destroy it. Raising the output of $17 \mathrm{KGS}$ or $17(\mathrm{OH}) \mathrm{CS} 50$ to 100 per cent. above the starting level resulted in the amelioration . or complete disappearance of symptoms and the regression of physical signs. This group will not be further considered as the subject of this paper is the effects of prolonged adrenocortical stimulation.

(B) Effects of Continuous Adrenocortical Stimulation for Periods exceeding 3 Months in 66 patients (Group B)

A total of 42 patients (18 women and 24 men), who received continuous adrenal stimulation for more than 3 months (average 16 mths), are listed in Table I (overleaf). They are referred to below as Group X.

Out of this total, 22 patients ( 7 women and 15 men: Nos. 21-42) received therapy for more than one year (average 25 months). They are referred to below as Group Y.

The severity of the disease was the same in the women as in the men, and the outcome of therapy was the same for both sexes. When the results of this study are compared with those of other therapeutic studies, this unusual preponderance of men need not therefore be considered.

Before starting adrenal stimulation therapy, all the patients had received aspirin, 27 had had phenylbutazone, seventeen gold, and fourteen cortisone (see Table I, footnotes).

Table I, which will be referred to repeatedly in the text, sets out the essential data for each patient, with the exception of the radiographic findings (Table VI).

(1) Effect upon the Disease Process.-Table I shows that the adrenal stimulation therapy given to these patients did not result in the eradication of the disease. This being so, it is necessary to compare the progress of these patients with that of a similar group who have not had adrenal stimulation therapy. The usual form of controlled trial was not possible and will remain impracticable until such time as we have corticotropin of a uniform potency which is not allergenic. The second best is to compare the progress of this group of patients with other groups treated and similarly assessed. This comparison is made below.

(a) Physical Ability.-The gradings used were as follows:

Grade 1 Physical abilities appropriate to age unimpaired.

Grade 2 Able to work or do normal housework but not up to Grade 1.

Grade 3 Major disabilities, mobility restricted, only able to do very light work.

Grade 4 Dependent on others for personal needs.

Grade 5 Bedfast.

Rheumatoid arthritic patients judge the value of their treatment mainly by the change in their physical ability. In this study 37 of the 42 improved by at least one grade and none fell to a lower grade during therapy (Table I, overleaf). The benefit cannot be entirely attributed to the adrenal stimulation therapy, however, for two reasons:

(i) The activity of the disease (which is the main determinant of physical ability except in very 
RECORD OF OBJECTIVE DATA FOR 42 INDIVIDUAL PATIENTS (GROUP X) SET OUT IN ORDER OF INCREASING

\begin{tabular}{|c|c|c|c|c|c|c|c|c|c|c|c|c|c|}
\hline \multirow{2}{*}{$\begin{array}{l}\text { Patient } \\
\text { No. }\end{array}$} & \multirow{2}{*}{$\begin{array}{l}\text { Previous } \\
\text { Therapy }\end{array}$} & \multirow{2}{*}{$\begin{array}{l}\text { Age at } \\
\text { Start of } \\
\text { Therapy }\end{array}$} & \multirow{2}{*}{ Sex } & \multirow{2}{*}{$\begin{array}{c}\text { Duration } \\
\text { of } \\
\text { Disease } \\
\text { at Start } \\
\text { (yrs) }\end{array}$} & \multirow{2}{*}{$\begin{array}{c}\text { Duration } \\
\text { of } \\
\text { Therapy } \\
\text { (mths) }\end{array}$} & \multicolumn{3}{|c|}{$\begin{array}{c}17 \mathrm{KGS} \text { or } 17(\mathrm{OH}) \mathrm{CS} \\
\text { Assays } \\
(\mathrm{mg} / 24 \mathrm{hrs})\end{array}$} & \multicolumn{2}{|c|}{ Physical Ability } & \multicolumn{3}{|c|}{$\begin{array}{l}\text { Strength of Grip } \\
\text { (Max. 260) }\end{array}$} \\
\hline & & & & & & Control & $\begin{array}{c}\text { Mean } \\
\text { Monthly } \\
\text { Level }\end{array}$ & $\begin{array}{l}\text { Last } \\
\text { Month of } \\
\text { Therapy }\end{array}$ & $\begin{array}{l}\text { At } \\
\text { Start }\end{array}$ & $\begin{array}{l}\text { Last } \\
\text { Month } \\
\text { of } \\
\text { Therapy }\end{array}$ & $\begin{array}{l}\text { At } \\
\text { Start }\end{array}$ & $\begin{array}{c}\text { Last } \\
\text { Month of } \\
\text { Therapy }\end{array}$ & $\begin{array}{l}\text { Maxiffum } \\
\text { Recoffded }\end{array}$ \\
\hline $\begin{array}{c}1 \\
2 \\
3 \\
4 \\
5 \\
5 \\
7 \\
8 \\
9 \\
10 \\
11 \\
12 \\
13 \\
14 \\
15 \\
16 \\
17 \\
18 \\
19 \\
* 20 \\
21 \\
* 22 \\
* 23 \\
* 24 \\
* 25 \\
* 26 \\
* 27 \\
* 28 \\
* 29 \\
* 30 \\
* 31 \\
* 32 \\
* 33 \\
* 34 \\
* 35 \\
* 36 \\
* 37 \\
* 38 \\
* 39 \\
* 40 \\
* 41 \\
* 42\end{array}$ & 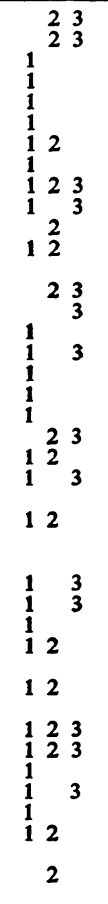 & $\begin{array}{l}41 \\
52 \\
50 \\
44 \\
47 \\
35 \\
47 \\
49 \\
53 \\
26 \\
45 \\
34 \\
55 \\
59 \\
23 \\
50 \\
37 \\
40 \\
49 \\
54 \\
42 \\
56 \\
45 \\
49 \\
35 \\
63 \\
47 \\
34 \\
32 \\
46 \\
33 \\
39 \\
45 \\
21 \\
46 \\
46 \\
37 \\
50 \\
68 \\
47 \\
15 \\
42\end{array}$ & $\begin{array}{c}\mathbf{F} \\
\mathbf{M} \\
\mathbf{F} \\
\mathbf{F} \\
\mathbf{M} \\
\mathbf{F} \\
\mathbf{M} \\
\mathbf{F} \\
\mathbf{M} \\
\mathbf{F} \\
\mathbf{M} \\
\mathbf{F} \\
\mathbf{M} \\
\mathbf{M} \\
\mathbf{F} \\
\mathbf{F} \\
\mathbf{F} \\
\mathbf{M} \\
\mathbf{M} \\
\mathbf{M} \\
\mathbf{M} \\
\mathbf{F} \\
\mathbf{F} \\
\mathbf{M} \\
\mathbf{M} \\
\mathbf{M} \\
\mathbf{M} \\
\mathbf{F} \\
\mathbf{M} \\
\mathbf{F} \\
\mathbf{M} \\
\mathbf{M} \\
\mathbf{M} \\
\mathbf{M} \\
\mathbf{M} \\
\mathbf{F} \\
\mathbf{M} \\
\mathbf{M} \\
\mathbf{M} \\
\mathbf{F}\end{array}$ & $\begin{array}{c}6 \\
2 \\
1 \\
1 \\
1 \\
1 \\
18 \\
1 \\
15 \\
2 \\
15 \\
5 \\
5 \\
5 \\
2 \\
9 \frac{1}{2} \\
9 \\
3 \frac{1}{2} \\
4 \\
4 \\
4 \\
3 \\
1 \\
16 \\
1 \\
3 \\
3 \\
2 \\
8 \\
4 \\
2 \frac{3}{2} \\
3 \\
12 \\
12 \\
2 \\
4 \\
3 \\
3 \\
\frac{1}{4}\end{array}$ & $\begin{array}{l}3 \\
3 \\
4 \\
4 \\
4 \\
4 \\
4 \\
4 \\
5 \\
5 \\
6 \\
6 \\
6 \\
6 \\
6 \\
6 \\
8 \\
9 \\
10 \\
10 \\
12 \\
12 \\
13 \\
13 \\
13 \\
14 \\
18 \\
18 \\
19 \\
24 \\
25 \\
27 \\
27 \\
29 \\
34 \\
36 \\
37 \\
38 \\
41 \\
45 \\
50\end{array}$ & $\begin{array}{l}X \\
12 \\
9 \\
10 \\
17 \\
10 \\
13 \\
8 \\
9 \\
X \\
12 \\
10 \\
9 \\
11 \\
9 \\
9 \\
X \\
14 \\
12 \\
14 \\
X \\
X \\
13 \\
13 \\
19 \\
13 \\
13 \\
X \\
X \\
X \\
10 \\
16 \\
16 \\
X \\
11 \\
12 \\
11 \\
4\end{array}$ & $\begin{array}{l}32 \\
18 \\
25 \\
29 \\
40 \\
30 \\
27 \\
34 \\
26 \\
23 \\
26 \\
26 \\
32 \\
30 \\
30 \\
36 \\
27 \\
27 \\
24 \\
25 \\
24 \\
27 \\
25 \\
18 \\
25 \\
24 \\
28 \\
26 \\
27 \\
23 \\
31 \\
39 \\
33 \\
31 \\
30 \\
25 \\
23 \\
28 \\
27 \\
31 \\
31 \\
20\end{array}$ & $\begin{array}{l}24 \\
22 \\
10 \\
20 \\
40 \\
30 \\
40 \\
36 \\
25 \\
20 \\
23 \\
27 \\
26 \\
22 \\
19 \\
20 \\
40 \\
38 \\
17 \\
18 \\
23 \\
19 \\
43 \\
12 \\
25 \\
16 \\
21 \\
46 \\
19 \\
24 \\
27 \\
55 \\
40 \\
21 \\
30 \\
29 \\
23 \\
25 \\
10 \\
27 \\
27 \\
12\end{array}$ & $\begin{array}{l}3 \\
2 \\
3 \\
4 \\
3 \\
3 \\
3 \\
3 \\
3 \\
3 \\
3 \\
3 \\
4 \\
4 \\
3 \\
4 \\
3 \\
33 \\
3 \\
33 \\
3 \\
3 \\
33 \\
3 \\
33 \\
3 \\
4 \\
33 \\
4 \\
4 \\
4 \\
33 \\
3 \\
4 \\
3 \\
4 \\
4 \\
33 \\
3 \\
3 \\
4 \\
4 \\
3\end{array}$ & $\begin{array}{l}2 \\
2\end{array}$ & 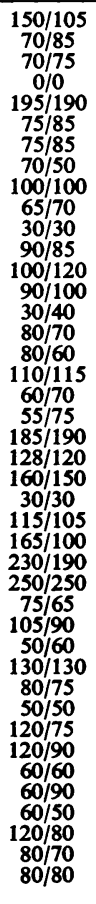 & 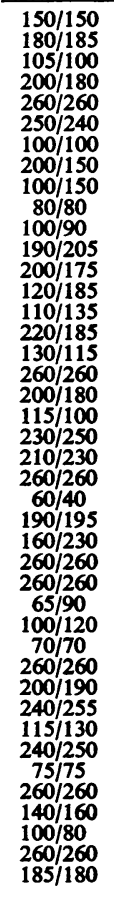 & 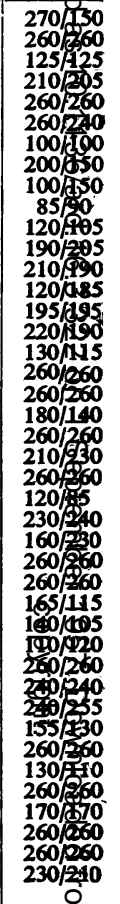 \\
\hline
\end{tabular}

Previous therapy: All had had aspirin; 1 =Plus phenylbutazone; 2 =Plus gold; $3=$ Plus cortisone. $\quad X=$ No assay.

$a=$ Polyarteritis nodose.

advanced states) waxes and wanes in an unpredictable manner, so that any group started on a particular therapy at a time of maximum disease activity (as in this group under study) are likely, as a group, to show less disease activity at any subsequent assessment.

(ii) Many previously untreated patients can have their physical ability improved by active physiotherapy alone (i.e. through some restoration of muscle power and through correction of deformity).

Table II (opposite) shows comparisons with other trials in which this Centre has been concerned. The mean findings for this study are recorded for the whole group $(\mathrm{X})$ and for those who have been treated for more than one year (Y). It will be noted that the Medical Research Council-Nuffield Foundation aspirin-cortisone trial included only early cases ( 3 to 9 months' duration). The prognosis for a group of early cases is much better than that for a group with a disease duration of 2 or more years.

(b) Strength of Grip.-In the majority of rheumatoid arthritics the state of the hands is the best single guide to the severity of the disease, and changes in the strength of grip are the best guide to changes in the activity of the disease. Strength of grip was measured, with a sewn-up sphygmomanometer cuff, at approximately the same time each day-after any morning stiffness had been worked off. $260 \mathrm{~mm}$. $\mathrm{Hg}$ was the maximum 
RATION OF THERAPY. PATIENTS 21-42 WHO RECEIVED THERAPY FOR ONE YEAR OR MORE COMPRISE GROUP Y

\begin{tabular}{|c|c|c|c|c|c|c|c|c|c|c|c|c|c|c|}
\hline \multicolumn{4}{|c|}{$\begin{array}{c}\text { Erythrocyte Sedimentation Rate } \\
\text { (Wintrobe) (mm./hr) }\end{array}$} & \multicolumn{4}{|c|}{ Haemoglobin $(\mathrm{g} . / 100 \mathrm{ml})}$. & \multicolumn{3}{|c|}{ Blood Pressure } & \multicolumn{4}{|c|}{ Weight (lb.) } \\
\hline$\underset{\text { Start }}{\text { At }}$ & $\begin{array}{l}\text { Mean of } \\
\text { Monthly } \\
\text { Records }\end{array}$ & $\begin{array}{l}\text { Mini- } \\
\text { mum } \\
\text { Re- } \\
\text { corded }\end{array}$ & $\begin{array}{l}\text { Last } \\
\text { Month } \\
\text { of } \\
\text { Therapy }\end{array}$ & $\underset{\text { Start }}{\text { At }}$ & $\begin{array}{l}\text { Mean of } \\
\text { Monthly } \\
\text { Records }\end{array}$ & $\begin{array}{c}\text { Maximum } \\
\text { Re- } \\
\text { corded }\end{array}$ & $\begin{array}{l}\text { Last } \\
\text { Month } \\
\text { of } \\
\text { Therapy }\end{array}$ & $\underset{\text { Start }}{\text { At }}$ & $\begin{array}{c}\text { Maximum } \\
\text { Re- } \\
\text { corded }\end{array}$ & $\begin{array}{l}\text { Last } \\
\text { Month } \\
\text { of } \\
\text { Therapy }\end{array}$ & $\begin{array}{c}\text { Maximum } \\
\text { Before } \\
\text { Onset of } \\
\text { Disease }\end{array}$ & $\underset{\text { Start }}{\text { At }}$ & $\begin{array}{c}\text { Maximum } \\
\text { During } \\
\text { Therapy }\end{array}$ & $\begin{array}{c}\text { Last } \\
\text { Month } \\
\text { of } \\
\text { Therapy }\end{array}$ \\
\hline $\begin{array}{l}35 \\
29 \\
59 \\
62 \\
53 \\
38 \\
45 \\
62 \\
47 \\
51 \\
44 \\
52 \\
50 \\
22 \\
42 \\
55 \\
17 \\
49 \\
41 \\
40 \\
57 \\
37 \\
57 \\
62 \\
15 \\
57 \\
27 \\
50 \\
50 \\
50 \\
47 \\
46 \\
27 \\
28 \\
22 \\
37 \\
26 \\
9 \\
27 \\
50 \\
50 \\
43\end{array}$ & $\begin{array}{r}27 \\
24 \\
36 \\
20 \\
41 \\
5 \\
11 \\
18 \\
22 \\
45 \\
22 \\
45 \\
14 \\
18 \\
35 \\
17 \\
18 \\
22 \\
21 \\
25 \\
35 \\
26 \\
23 \\
36 \\
5 \\
36 \\
25 \\
34 \\
12 \\
41 \\
19 \\
24 \\
5 \\
17 \\
17 \\
25 \\
9 \\
7 \\
19 \\
12 \\
21 \\
18\end{array}$ & $\begin{array}{r}25 \\
5 \\
32 \\
4 \\
18 \\
5 \\
10 \\
6 \\
9 \\
43 \\
8 \\
28 \\
6 \\
7 \\
34 \\
5 \\
2 \\
7 \\
4 \\
14 \\
20 \\
5 \\
11 \\
19 \\
2 \\
7 \\
5 \\
10 \\
3 \\
26 \\
6 \\
11 \\
2 \\
4 \\
5 \\
6 \\
3 \\
3 \\
3 \\
2 \\
2 \\
4\end{array}$ & $\begin{array}{r}32 \\
13 \\
37 \\
8 \\
49 \\
5 \\
10 \\
6 \\
9 \\
45 \\
8 \\
48 \\
10 \\
7 \\
34 \\
19 \\
10 \\
7 \\
24 \\
30 \\
20 \\
5 \\
11 \\
54 \\
4 \\
40 \\
20 \\
34 \\
14 \\
26 \\
35 \\
20 \\
2 \\
14 \\
15 \\
18 \\
13 \\
3 \\
13 \\
10 \\
3 \\
27\end{array}$ & $\begin{array}{r}9 \cdot 7 \\
13 \cdot 7 \\
10 \cdot 2 \\
10 \cdot 2 \\
10 \\
15 \cdot 9 \\
10 \cdot 8 \\
8 \cdot 7 \\
12 \cdot 6 \\
11 \cdot 1 \\
11 \cdot 3 \\
10 \cdot 2 \\
15 \cdot 1 \\
13 \cdot 7 \\
6 \cdot 1 \\
10 \cdot 5 \\
13 \cdot 3 \\
12 \cdot 6 \\
11 \cdot 4 \\
13 \cdot 4 \\
7 \cdot 9 \\
14 \cdot 1 \\
9 \cdot 7 \\
8 \cdot 7 \\
12 \cdot 3 \\
10 \cdot 8 \\
13 \\
14 \cdot 1 \\
10 \\
10 \cdot 7 \\
12 \cdot 3 \\
14 \cdot 1 \\
14 \cdot 2 \\
13 \cdot 7 \\
13 \\
15 \cdot 5 \\
11 \cdot 1 \\
16 \cdot 5 \\
13 \cdot 7 \\
12 \cdot 6 \\
10 \cdot 8 \\
11\end{array}$ & $\begin{array}{l}10 \cdot 3 \\
15 \cdot 5 \\
12 \\
12 \cdot 8 \\
11 \cdot 6 \\
16 \\
13 \cdot 5 \\
12 \cdot 1 \\
13 \cdot 4 \\
10 \cdot 3 \\
11 \cdot 3 \\
12 \cdot 5 \\
16 \cdot 5 \\
14 \\
8 \\
15 \\
13 \cdot 4 \\
14 \\
14 \cdot 6 \\
14 \cdot 3 \\
8 \cdot 8 \\
14 \cdot 8 \\
11 \cdot 7 \\
10 \cdot 4 \\
14 \cdot 4 \\
12 \cdot 5 \\
14 \cdot 2 \\
12 \cdot 5 \\
12 \cdot 3 \\
13 \\
9 \\
14 \\
16 \cdot 3 \\
15 \\
15 \cdot 5 \\
15 \cdot 7 \\
10 \cdot 5 \\
16 \cdot 7 \\
13 \cdot 3 \\
16 \cdot 5 \\
13 \cdot 7 \\
14\end{array}$ & $\begin{array}{l}11 \cdot 3 \\
16 \cdot 4 \\
13 \\
15 \cdot 1 \\
11 \cdot 6 \\
16 \\
14 \cdot 5 \\
14 \\
14 \cdot 1 \\
11 \cdot 6 \\
12 \cdot 3 \\
13 \cdot 7 \\
16 \cdot 7 \\
15 \cdot 5 \\
9 \cdot 9 \\
16 \cdot 2 \\
15 \cdot 1 \\
15 \cdot 5 \\
17 \cdot 5 \\
15 \cdot 5 \\
10 \cdot 6 \\
15 \cdot 9 \\
14 \cdot 1 \\
13 \\
15 \cdot 5 \\
13 \cdot 7 \\
15 \cdot 3 \\
14 \cdot 5 \\
13 \cdot 7 \\
14 \cdot 8 \\
12 \cdot 6 \\
15 \cdot 5 \\
18 \\
15 \cdot 9 \\
16 \cdot 4 \\
17 \cdot 5 \\
12 \cdot 6 \\
18 \\
15 \cdot 5 \\
17 \cdot 5 \\
16 \cdot 9 \\
16 \cdot 4\end{array}$ & $\begin{array}{l}10 \cdot 5 \\
16 \cdot 4 \\
11 \cdot 9 \\
15 \cdot 1 \\
10 \cdot 2 \\
16 \\
14 \cdot 5 \\
14 \\
14 \cdot 1 \\
9 \\
10 \cdot 8 \\
12 \cdot 3 \\
15 \cdot 9 \\
15 \cdot 5 \\
9 \cdot 9 \\
15 \cdot 1 \\
12 \cdot 6 \\
13 \cdot 8 \\
14 \cdot 2 \\
14 \cdot 5 \\
9 \cdot 9 \\
15 \cdot 6 \\
12 \cdot 6 \\
13 \\
14 \\
12 \cdot 7 \\
15 \cdot 3 \\
14 \cdot 5 \\
10 \cdot 8 \\
14 \cdot 2 \\
12 \cdot 3 \\
15 \cdot 5 \\
16 \cdot 3 \\
15 \cdot 2 \\
14 \cdot 5 \\
14 \cdot 5 \\
10 \cdot 2 \\
18 \\
13 \cdot 6 \\
16 \cdot 4 \\
14 \\
13 \\
13\end{array}$ & $\begin{array}{l}140 / 90 \\
130 / 85 \\
120 / 70 \\
130 / 80 \\
145 / 80 \\
130 / 85 \\
135 / 70 \\
130 / 80 \\
155 / 96 \\
135 / 85 \\
110 / 70 \\
115 / 70 \\
115 / 80 \\
150 / 80 \\
105 / 75 \\
110 / 70 \\
140 / 90 \\
115 / 70 \\
170 / 70 \\
145 / 85 \\
150 / 85 \\
115 / 75 \\
120 / 70 \\
125 / 75 \\
130 / 85 \\
180 / 110 \\
145 / 80 \\
180 / 90 \\
140 / 85 \\
125 / 75 \\
120 / 80 \\
130 / 70 \\
125 / 90 \\
110 / 80 \\
130 / 80 \\
120 / 80 \\
120 / 75 \\
130 / 80 \\
150 / 100 \\
120 / 80 \\
120 / 70 \\
130 / 80 \\
\end{array}$ & $\begin{array}{l}160 / 110 \\
145 / 90 \\
200 / 95 \\
160 / 110 \\
150 / 85 \\
145 / 90 \\
160 / 85 \\
190 / 95 \\
170 / 100 \\
135 / 85 \\
150 / 110 \\
140 / 90 \\
140 / 100 \\
170 / 80 \\
120 / 75 \\
150 / 90 \\
180 / 95 \\
115 / 75 \\
175 / 100 \\
190 / 120 \\
160 / 100 \\
160 / 90 \\
140 / 90 \\
120 / 80 \\
130 / 90 \\
180 / 110 \\
150 / 90 \\
190 / 110 \\
165 / 115 \\
165 / 110 \\
160 / 100 \\
160 / 110 \\
180 / 110 \\
160 / 100 \\
160 / 100 \\
140 / 95 \\
135 / 90 \\
140 / 85 \\
120 / 115 \\
210 / 110 \\
140 / 80 \\
160 / 100\end{array}$ & $\begin{array}{l}170 / 105 \\
140 / 85 \\
160 / 80 \\
140 / 100 \\
150 / 85 \\
115 / 75 \\
160 / 85 \\
180 / 90 \\
155 / 95 \\
120 / 65 \\
150 / 90 \\
140 / 90 \\
155 / 90 \\
160 / 80 \\
120 / 75 \\
135 / 95 \\
180 / 95 \\
100 / 70 \\
185 / 90 \\
190 / 120 \\
155 / 100 \\
160 / 90 \\
130 / 85 \\
110 / 60 \\
130 / 90 \\
170 / 105 \\
140 / 90 \\
190 / 110 \\
150 / 100 \\
150 / 100 \\
135 / 90 \\
160 / 110 \\
180 / 100 \\
125 / 80 \\
130 / 90 \\
120 / 80 \\
150 / 80 \\
135 / 80 \\
130 / 80 \\
190 / 100 \\
135 / 60 \\
180 / 90 \\
\end{array}$ & $\begin{array}{l}136 \\
144 \\
112 \\
166 \\
161 \\
130 \\
140 \\
115 \\
204 \\
116 \\
128 \\
146 \\
179 \\
136 \\
163 \\
130 \\
129 \\
162 \\
146 \\
152 \\
145 \\
166 \\
156 \\
129 \\
112 \\
146 \\
161 \\
168 \\
161 \\
140 \\
142 \\
150 \\
173 \\
110 \\
134 \\
182 \\
116 \\
171 \\
154 \\
161 \\
100 \\
136\end{array}$ & $\begin{array}{l}128 c \\
142 c \\
104 \\
136 \\
155 \\
124 \\
125 \\
96 \\
204 c \\
121 c \\
109 \\
102 \\
131 \\
177 c \\
102 b c \\
108 \\
117 c \\
147 \\
126 \\
144 \\
138 c \\
146 \\
160 c \\
93 \\
102 \\
133 \\
153 \\
182 c \\
158 c \\
130 c \\
111 \\
147 \\
161 \\
101 \\
130 c \\
143 \\
106 \\
171 c \\
111 \\
137 \\
97 \\
127\end{array}$ & $\begin{array}{l}148 \\
145 \\
120 \\
149 \\
167 \\
132 \\
145 \\
118 \\
214 \\
124 \\
127 \\
113 \\
151 \\
194 \\
133 \\
135 \\
140 \\
162 \\
148 \\
152 \\
143 \\
173 \\
179 \\
128 \\
129 \\
139 \\
180 \\
199 \\
193 \\
153 \\
126 \\
177 \\
172 \\
124 \\
163 \\
166 \\
139 \\
190 \\
144 \\
170 \\
124 \\
145\end{array}$ & $\begin{array}{l}148 \\
145 \\
120 \\
148 \\
167 \\
132 \\
145 \\
110 \\
209 \\
120 \\
126 \\
112 \\
151 \\
185 \\
130 \\
135 \\
140 \\
156 \\
141 \\
150 \\
135 \\
173 \\
169 \\
119 \\
128 \\
139 \\
180 \\
199 \\
193 \\
149 \\
124 \\
168 \\
171 \\
110 \\
163 \\
157 \\
139 \\
190 \\
144 \\
151 \\
118 \\
137\end{array}$ \\
\hline
\end{tabular}

Ulcerative colitis. $\quad c=$ Previous cortisone therapy. $\quad d=$ Scleroderma. $\quad+=$ Febrile at the time. $\quad=$ Radiological findings detailed in Table VI.

TABLE II

CHANGE OBSERVED IN PHYSICAL ABILITY IN THIS AND OTHER STUDIES

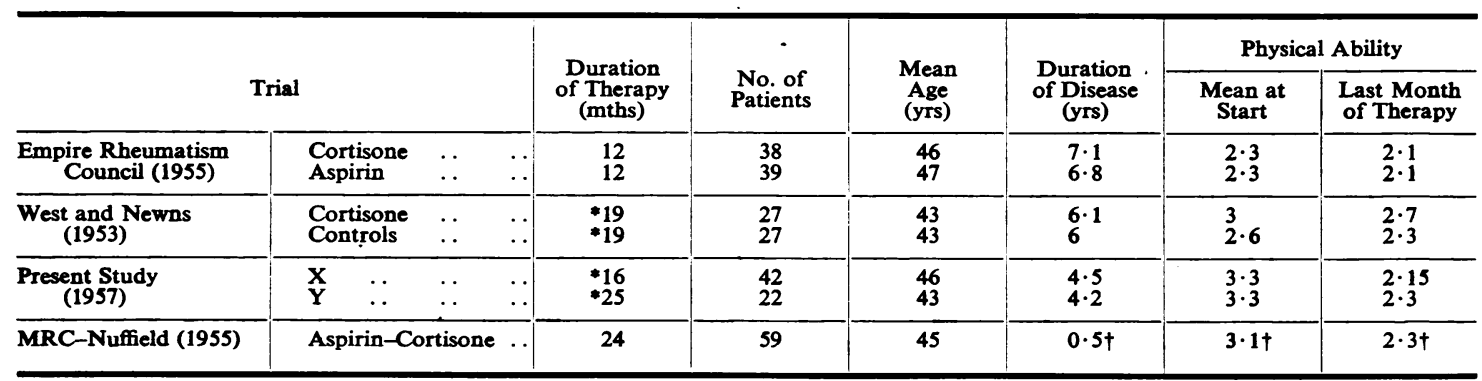


possible reading. The results are shown in Table III.

TABLE III

RESULTS OF TESTS OF HAND GRIP

\begin{tabular}{c|c|c|c|c|c}
\hline \multirow{2}{*}{ Group } & \multirow{2}{*}{$\begin{array}{c}\text { No. of } \\
\text { Patients }\end{array}$} & Hand & \multicolumn{2}{|c|}{ Mean Strength of Grip (mm. Hg) } \\
\cline { 3 - 5 } & & At Start & $\begin{array}{c}\text { Maximum } \\
\text { Recorded }\end{array}$ & $\begin{array}{c}\text { Last } \\
\text { Month of } \\
\text { Therapy }\end{array}$ \\
\hline X & 42 & Right & 96 & 200 & 175 \\
\hline Y & 22 & Left & 91 & 193 & 175 \\
\hline & Right & 110 & 211 & 180 \\
\hline
\end{tabular}

Table I shows that in only one individual patient did the mean strength of grip $(R+L)$ fall below the starting level. The fact that the last recorded figures are below the maximum figures is mainly due to the fact that the strength of grip is highest when the adrenal stimulation is highest, and a similar state of affairs is seen when the E.S.R., Hb, blood pressure, and weight records are studied. At some time during the study each patient will have been stimulated to a level well above his mean level. The mean level of $17 \mathrm{KGS}$ or $17(\mathrm{OH}) \mathrm{CS}$ output for the last month of the entire group was $26 \mathrm{mg}$. and the mean of the means for the total duration of therapy was $28 \mathrm{mg}$. The only valid comparison for strength of grip is with the group of cortisonetreated patients referred to by West and Newns (1953); in this study the mean strength of grip of the 27 patients rose from $105 / 100$ to $155 / 153$ in the course of 19 months. This group had a mean disease duration of $6 \cdot 1$ years compared with $4 \cdot 5$ and $4 \cdot 2$ in this study. In the Medical Research Council-Nuffield Foundation Aspirin-Cortisone Trial (1955), mean figures for grip are not given, but it is stated that the strength of grip deteriorated to some degree in fourteen out of 59 . In the M.R.C. - Nuffield Cortisone versus Prednisone Trial (1957), the mean strength of grip of the thirty cortisone patients changed from $135 / 136$ to $129 / 137$ (1 year), and that of the 33 prednisone patients from $1371 / 36$ to $150 / 155$, but again the disease of the patients was of longer duration than that of our adrenal stimulation group.

(c) Erythrocyte Sedimentation Rate (Wintrobe). - Means obtained in Groups $\mathrm{X}$ and $\mathrm{Y}$ and comparisons with results in other trials are given in Table IV.

(d) Haemoglobin Levels (oxyhaemoglobin method).--Means obtained in Groups $\mathbf{X}$ and $\mathbf{Y}$ and comparisons with other trials are shown in Table V (opposite).

(e) Radiographic Changes.-The 22 patients who received continuous adrenal stimulation therapy for 12 months or more (average 25 months) had follow-up radiographs taken of their hands, which were clinically affected in every case. The films taken covered an average period of $25 \frac{1}{2}$ months. (In a few cases the period covered included a few months at the beginning or end of the study during which sub-therapeutic levels of stimulation were given-months not included in the "duration of therapy"). The findings in Table VI (opposite) do not include changes in bone density, since estimates of such changes are liable, for technical reasons, to be unreliable. It can be said that no gross changes were observed. It will be seen that in only two cases (or possibly three) were advances noted in the size of erosions or new erosions seen. Some loss of joint space was observed in a further three cases. The appearance described as "healing" consisted of a replacement of the frayed edges of an erosion by dense bone.

TABLE IV

COMPARISON OF MEAN CHANGE IN ERYTHROCYTE SEDIMENTATION RATE IN VARIOUS TRIALS

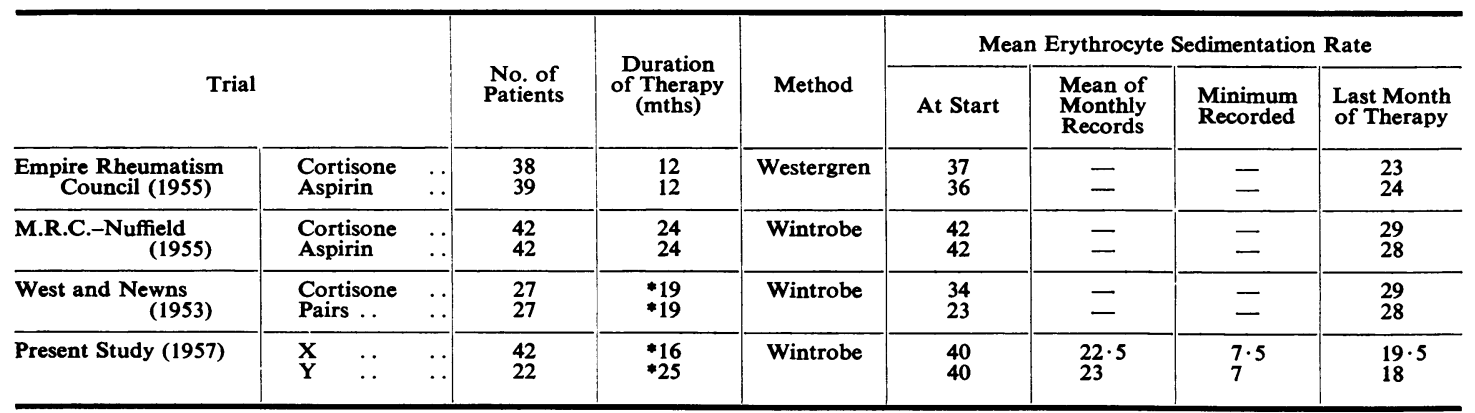

* Mean duration. 
TABle V

COMPARISON OF MEAN CHANGE IN HAEMOGLOBIN LEVELS IN VARIOUS TRIALS

\begin{tabular}{|c|c|c|c|c|c|c|c|c|}
\hline \multirow[b]{2}{*}{ Tria } & & & \multirow[b]{2}{*}{$\begin{array}{l}\text { No. of } \\
\text { Patients }\end{array}$} & \multirow[b]{2}{*}{$\begin{array}{l}\text { Duration } \\
\text { of Therapy } \\
\text { (mths) }\end{array}$} & \multicolumn{4}{|c|}{ Mean Hb (g.) } \\
\hline & & & & & At Start & $\begin{array}{l}\text { Mean of } \\
\text { Monthly } \\
\text { Records }\end{array}$ & $\begin{array}{l}\text { Maximum } \\
\text { Recorded }\end{array}$ & $\begin{array}{l}\text { Last Month } \\
\text { of Therapy }\end{array}$ \\
\hline $\begin{array}{l}\text { Empire Rheumatism } \\
\text { Council (1955) }\end{array}$ & $\begin{array}{l}\text { Cortisone } \\
\text { Aspirin }\end{array}$ & $\cdots$ & $\begin{array}{l}38 \\
39\end{array}$ & $\begin{array}{l}12 \\
12\end{array}$ & $\begin{array}{l}12 \cdot 5 \\
12 \cdot 5\end{array}$ & - & - & $\begin{array}{l}13 \cdot 3 \\
13 \cdot 1\end{array}$ \\
\hline $\begin{array}{l}\text { M.R.C.-Nuffield } \\
\text { (1955) }\end{array}$ & $\begin{array}{l}\text { Cortisone } \\
\text { Aspirin }\end{array}$ & 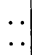 & $\begin{array}{l}30 \\
28\end{array}$ & $\begin{array}{l}24 \\
24\end{array}$ & $\begin{array}{l}12 \cdot 2 \\
12 \cdot 1\end{array}$ & 二 & - & $\begin{array}{l}13 \cdot 0 \\
12 \cdot 3\end{array}$ \\
\hline $\begin{array}{l}\text { West and Newns } \\
\text { (1953) }\end{array}$ & $\begin{array}{l}\text { Cortisone } \\
\text { Pairs ... }\end{array}$ & $\begin{array}{l}\cdots \\
\cdots\end{array}$ & $\begin{array}{l}27 \\
27\end{array}$ & $\begin{array}{l}* 19 \\
* 19\end{array}$ & $\begin{array}{l}11 \cdot 3 \\
13 \cdot 5\end{array}$ & - & 二 & $\begin{array}{l}12 \cdot 3 \\
13 \cdot 3\end{array}$ \\
\hline $\begin{array}{l}\text { Present Study } \\
\text { (1957) }\end{array}$ & $\begin{array}{ll}\mathbf{X} & \cdots \\
\mathbf{Y} & \cdots\end{array}$ & $\begin{array}{l}\ldots \\
\cdots\end{array}$ & $\begin{array}{l}42 \\
22\end{array}$ & $\begin{array}{l}* 16 \\
* 25\end{array}$ & $\begin{array}{l}11 \cdot 9 \\
12 \cdot 3\end{array}$ & $\begin{array}{l}13 \cdot 2 \\
13 \cdot 4\end{array}$ & $\begin{array}{l}14 \cdot 8 \\
15 \cdot 2\end{array}$ & $\begin{array}{l}13 \cdot 6 \\
14 \cdot 0\end{array}$ \\
\hline
\end{tabular}

- Mean duration.

TABLE VI

CHANGES NOTED IN BONE EROSIONS IN HAND RADIOGRAPHS IN 22 PATIENTS ARRANGED IN ORDER OF DURATION OF THERAPY AND HENCE IN ORDER OF LENGTH OF INTERVAL BETWEEN $X$-RAY EXAMINATIONS

\begin{tabular}{|c|c|c|c|c|c|c|c|c|}
\hline \multirow[t]{2}{*}{$\begin{array}{l}\text { Patient } \\
\text { No. }\end{array}$} & \multirow{2}{*}{$\begin{array}{c}\text { Age at } \\
\text { Start of } \\
\text { Therapy } \\
\text { (yrs) }\end{array}$} & \multirow[t]{2}{*}{ Sex } & \multirow{2}{*}{$\begin{array}{c}\text { Duration } \\
\text { of Disease } \\
\text { at Start of } \\
\text { Therapy } \\
\text { (yrs) }\end{array}$} & \multirow{2}{*}{$\begin{array}{l}\text { Duration } \\
\text { of Therapy } \\
\text { (mths) }\end{array}$} & \multirow{2}{*}{$\begin{array}{c}\text { Average } \\
\text { Level } \\
17 \mathrm{KGS} \text { or } \\
17(\mathrm{OH}) \mathrm{CS}\end{array}$} & $\underset{\text { Erosions }}{X \text {-ray Bone }}$ & \multirow{2}{*}{$\begin{array}{l}\text { Interval } \\
\text { between } \\
X \text { Rays }\end{array}$} & \multirow[t]{2}{*}{ Change in Erosions } \\
\hline & & & & & & $\overline{(0 ;+;++)}$ & & \\
\hline 20 & 54 & $\mathbf{M}$ & 4 & 10 & 25 & $\mathbf{0}$ & 12 & No change \\
\hline 23 & 45 & $\mathbf{F}$ & 3 & 12 & 25 & + & 12 & No change \\
\hline 24 & 49 & $\mathbf{F}$ & 1 & 13 & 18 & + & 12 & Healing \\
\hline 25 & 35 & $\mathbf{F}$ & 16 & 13 & 25 & O & 12 & No change \\
\hline 26 & 63 & $\mathbf{M}$ & 1 & 14 & 24 & 0 & 12 & No change \\
\hline 28 & 34 & $\mathbf{M}$ & 3 & 18 & 26 & + & 12 & No change \\
\hline 29 & 32 & $\mathbf{F}$ & 2 & 18 & 27 & + & 15 & No change \\
\hline 27 & 47 & $\mathbf{M}$ & $\frac{9}{2}$ & 18 & 28 & + & 18 & Healing \\
\hline 22 & 56 & $\mathbf{M}$ & 4 & 12 & 27 & + & 19 & Slight advance in previous erosion $\dagger$ \\
\hline 30 & 46 & $\mathbf{M}$ & 8 & 19 & 23 & ++ & 21 & No change* \\
\hline 31 & 33 & $\mathbf{F}$ & 4 & 24 & 31 & ++ & 23 & No change \\
\hline 35 & 46 & $\mathbf{M}$ & 12 & 29 & 30 & $\mathbf{O}$ & 23 & No change \\
\hline 32 & 39 & $\mathbf{M}$ & $\frac{1}{2}$ & 25 & 39 & $\mathbf{O}$ & 24 & No change \\
\hline 33 & 45 & $\mathbf{M}$ & 2 & 27 & 33 & ++ & 27 & Healing \\
\hline 34 & 21 & $\mathbf{M}$ & 3 & 27 & 31 & ++ & 28 & Healing \\
\hline 37 & 37 & $\mathbf{F}$ & 2 & 36 & 23 & $\mathbf{O}$ & 36 & No change \\
\hline 38 & 50 & $\mathbf{M}$ & 4 & 37 & 28 & + & 40 & No change* \\
\hline 39 & 68 & $\mathbf{F}$ & 4 & 38 & 27 & + & 40 & No change $\ddagger$ \\
\hline 40 & 47 & $\mathbf{M}$ & 3 & 41 & 31 & ++ & 41 & $\begin{array}{l}\text { New erosion } \\
\text { Advance in previous erosion }\end{array}$ \\
\hline 41 & 15 & $\mathbf{M}$ & 1 & 45 & 31 & O & 42 & No change§ \\
\hline 36 & 46 & $\mathbf{M}$ & 12 & 34 & 25 & + & 43 & No change* \\
\hline 42 & 42 & $\mathbf{F}$ & 2 & 50 & 20 & ++ & 54 & $\begin{array}{l}\text { Advance } \\
\text { No new erosions }\end{array}$ \\
\hline
\end{tabular}

- Some apparent loss of joint space.

This may have occurred in the 7 months before therapy was begun.

$\ddagger$ Dense calcium deposits about phalanges resorbed almost com- pletely. No detectable change in bone density of lumbar spine after $\mathbf{3 0}$ months therapy.

$\S$ Epiphyses fused normally during therapy. 
The findings in the other trials referred to previously do not provide comparable data except that of West and Newns (1953). In that trial fifteen of twenty cortisone patients and twelve of twenty controls showed an advance in erosions over an average period of 19 months. As the difference between these findings and those of the present trial were so marked, the radiographs of the 1953 trial were reviewed. Those of nineteen patients were found and on re-reading them, using the same criteria as for the present study, the findings were as follows:

Ten of the nineteen had bony erosions of the hands at the start and twelve showed an advance in erosions and/or new erosions. Two others showed some loss of joint space.

In the Empire Rheumatism Council's AspirinCortisone Trial (1955) in a period of one year, the average number of joints radiologically affected for the first time was two per patient (joint narrowing and/or erosions were counted.)

In the Medical Research Council-Nuffield Foundation Cortisone versus Prednisone Trial (1957), ten of 24 cortisone patients and nine of 27 prednisone patients had evidence of advance in bone erosion at the end of one year. Both hand and foot radiographs were examined, but this did not double the number of patients showing an advance in erosions, since in most cases an advance in bone erosion of the hands was accompanied by similar changes in the feet (personal observation).

\section{(2) OTHER EFFECTS}

(a) Blood Pressure.-Table VII gives the record of mean blood pressure for the groups at the beginning of treatment, at the end of the last month of treatment, and the maximum level recorded during treatment

As with other data presented, the maximum readings occurred at times of maximal adrenal stimulation, and the lower final readings were not due to a fall occasioned by prolonged therapy. The interest in these blood pressure readings lies in the individual variations to be seen in Table $I$. Patient 20 (a male aged 54) developed hypertension, whereas Patients 35 and 36 (males aged 46) did not do so although they had a higher output of $17(\mathrm{OH}) \mathrm{CS}$ for three times as long. Patient 26, who started with hypertension, showed no sign of a further rise during a year's therapy. Patient 39 (a female aged 68) had a slightly lower blood pressure after more than 3 years therapy, as did Patient 41 (a boy aged 15) after nearly 4 years of therapy. Nevertheless, there was a general tendency for blood pressures to rise, and a few individuals are clearly not suitable for this form of therapy.

(b) Weight.-Table VIII gives the mean of the weight records at various times. It will be seen that the last weight recorded is little above the best weight reached before the onset of the disease. Table I shows that in individual patients weight was put on greatly in excess of previous maxima,

TABLE VII

MEAN BLOOD PRESSURE RECORDS AT START AND END OF THERAPY AND MAXIMUM RECORDED DURING TREATMENT

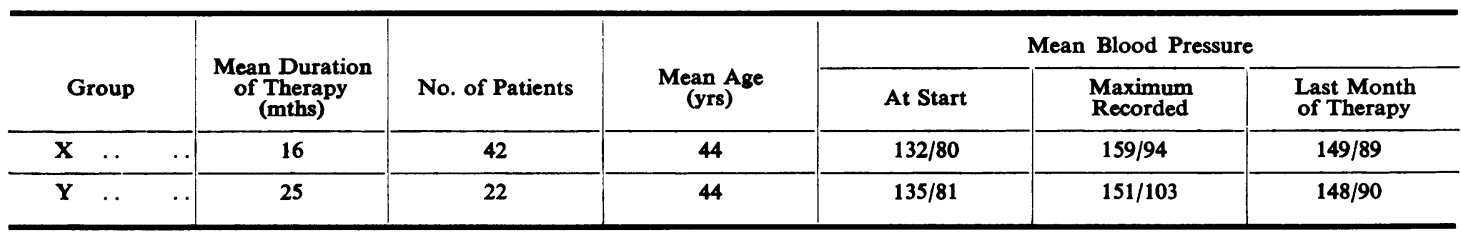

TABLE VIII

MEAN WEIGHT RECORDS AT START AND END OF THERAPY, WITH MEAN MAXIMUM WEIGHT DURING THERAPY AND MAXIMUM WEIGHT BEFORE ONSET OF ARTHRITIS

\begin{tabular}{|c|c|c|c|c|c|c|c|c|}
\hline \multirow{2}{*}{\multicolumn{2}{|c|}{ Group }} & & \multirow{2}{*}{$\begin{array}{c}\text { Mean Duration } \\
\text { of Therapy } \\
\text { (mths) }\end{array}$} & \multirow[b]{2}{*}{ No. of Patients } & \multicolumn{4}{|c|}{ Mean Weight (lb.) } \\
\hline & & & & & $\begin{array}{l}\text { Maximum before } \\
\text { Onset of Disease }\end{array}$ & At Start & $\begin{array}{c}\text { Maximum } \\
\text { during Therapy }\end{array}$ & $\begin{array}{l}\text { Last Month } \\
\text { of Therapy }\end{array}$ \\
\hline $\mathbf{X}$ & $\cdots$ & $\cdots$ & 16 & 42 & 145 & 132 & 152 & 148 \\
\hline $\mathbf{Y}$ & . & $\ldots$ & 25 & 22 & 145 & 133 & 157 & 152 \\
\hline
\end{tabular}


but that other patients treated for an equal or longer period showed no such increase. Most of the weight gained was of natural distribution and included muscle, as is evidenced, particularly in previously debilitated patients, by a steady rise in creatinine excretion.

(c) Hirsuties.-No particular attention was paid to the growth of facial hair. No coarse growths were seen in females, but some drew attention to an increase in downy hair and some males noted a stronger growth in the beard area.

One patient volunteered the information that the skin of her legs used to be dryish and sparsely covered with coarse hair but that the skin became soft and the coarse hair disappeared during therapy.

(d) Pigmentation.- The relatively crude corticotropins contained enough melanocyte-stimulating hormone to cause marked pigmentation in darkhaired individuals. Since oxycel-purified corticotropin became available, pigmentation has ceased to be noticeable.

(e) Function of Other Endocrine Glands.-No clinical evidence of hypo- or hyper-thyroid activity was noted. The impression was gained that in some patients irregular menstrual function was corrected during therapy and that in others excessive adrenal stimulation may have caused menstrual irregularities. The only undoubted effect was on Patient 15 (a female aged 23) who had severe rheumatoid arthritis and ulcerative colitis; she made a remarkable recovery and started to menstruate again after an interval of 3 years. Sexual function returned to normal in previously ill patients. A few patients developed glycosuria during excessive adrenocortical stimulation, but this was corrected by better control of the therapy.

( $f$ ) Wellbeing.-As with oral corticosteroid therapy, the access of energy and wellbeing to many previously debilitated patients was, to them, little short of miraculous. Although this awareness of wellbeing ceased to be noticeable as the months went by, patients did not sink back into a state of lassitude as is so commonly seen in prolonged oral corticosteroid therapy.

(3) Complications.-During this $4 \frac{1}{2}$-year period of adrenal stimulation therapy, only one death occurred that was in any way related to therapy. This patient, who had suffered from severe rheumatoid arthritis for many years, was changed from delta-1 cortisol (prednisolone) to adrenal stimulation therapy; she had a year previously acquired resistance to corticotropin but on this occasion was given a more purified preparation; she made a rapid and excellent response, but as rapidly re-acquired resistance, and although only "hypo-adrenal" for one day before cortisone was given she became psychotic and was transferred to a mental hospital where she died 5 days later.

Two other patients died in the course of the study. One had Simmonds' disease and rheumatoid arthritis; he relapsed severely on acquiring resistance to relatively crude corticotropin and was given delta-1 cortisone (prednisone) instead; he died of a pulmonary embolus 6 months later and some evidence of polyarteritis was found at autopsy. The second was a patient whose rheumatoid arthritis was complicated by asthma; her treatment was changed to delta-1 cortisol because of incipient congestive heart failure; she died of an overdose of a barbiturate a year later.

The much-discussed complications of corticosteroid therapy are peptic ulceration and its consequences, and less commonly severe, initially symptomless, bacterial infections. No such complications occurred during the $4 \frac{1}{2}$ years of adrenal stimulation therapy. The therapy entailed many thousands of self-administered injections but only one abscess was seen.

Further complications referred to in accounts of corticosteroid and corticotropin therapy are:

(i) excessive loss of potassium to be prevented by giving potassium chloride;

(ii) a negative nitrogen balance due to protein catabolism which may be prevented by a high protein diet;

(iii) loss of calcium leading to osteoporosis and compression fractures of vertebrae.

The patients in this study had no potassium chloride supplements, and pleased themselves as to what they ate. As a group they have more strength and more muscle than before therapy. No special study was made of the vertebral bone density, but the patient thought most likely to develop spinal osteoporosis (Patient 39, who has had more than 3 years of adrenal stimulation since her 68th birthday) has shown no radiological evidence of increased porosis.

The complications that did occur were as follows:

(a) Acquired Sensitivity to Corticotropin.-Many patients acquired the ability to destroy the administered corticotropin, including oxycel-purified preparations, but few developed allergic manifestations. The subject has already been discussed fully (West, 1956). Since the report referred to was made, a further patient has had an anaphylactic reaction to highly-purified corticotropin and has been subsequently successfully treated with corticotropin $A_{1}$ (of Dixon and Stack-Dunne) without evidence of local or general allergic reactions. 
(b) Hypertension.-As stated above, eight patients had to stop therapy because it had induced hypertension. The evidence available suggests that the hypertension is reversible.

(c) Fluid Retention with Postural Oedema.-No reason was apparent for this complication in the few patients affected. The oedema disappeared on withdrawing therapy.

(d) Cardiac Embarrassment.-Two patients had to stop for this reason-clearly caused by an extra load being placed upon the heart.

(e) Psychosis.-Two patients had psychotic episodes from which they recovered. I do not think that either episode would have occurred if the adrenal stimulation therapy had been better controlled.

\section{Discussion}

Before discussing the clinical effects of "adrenocortical stimulation therapy", some consideration of the nature of this therapy is relevant. It has consisted in the daily intramuscular injection of an extract of porcine or bovine pituitaries, usually in a gelatin medium. Biological assay suggests that 10 to 50 per cent. of the extract is "adrenocorticotropic hormone", and clinical study incriminates the remainder as the source of antigen responsible for inducing "acquired resistance" and allergic reactions (West, 1956). This remainder contains speciesspecific protein (unpublished finding), and could, theoretically, induce disease states other than local allergy and anaphylactic shock. Corticotropin with a purity comparable to re-crystallized insulin is desirable. There may be slight structural differences between the corticotropins in use-porcine, bovine, ovine, and cetacean-but there is as yet no evidence that they differ in their effects in man.

After parenteral administration, a variable amount of corticotropin reaches the adrenal where it promotes steroidogenesis and steroid secretion. Corticotropins may also have separate adrenocortical growth-promoting activity and fatmobilizing activity, but insufficient is known of these effects to include them in this discussion. From the evidence at present available, exogenous corticotropin (given to adults) promotes an increase in all the known steroids of the adrenal secretion with the exception of aldosterone. The secretion of aldosterone can be affected secondarily and in some cases perhaps primarily-the evidence so far accumulated is still fragmentary. When using the 17-ketogenic assay (which necessitates the assay of 17 -ketosteroids) it is seen that the ratio of $17 \mathrm{KGS}$ to $17 \mathrm{KS}$ varies from patient to patient and may vary in the same patient from time to time. The significance of this is not known. It is possible that in some patients prolonged adrenocortical stimulation may result in a qualitatively abnormal secretion-this possibility has not yet been studied. As a result of adrenal stimulation therapy, the endogenous adrenocorticotropic hormone ceases to circulate and the usual diurnal rhythm of steroid secretion is replaced by a much greater rise and fall. Normally the adrenal secretion is lowest at night, whereas for most of the patients studied it has been highest at night. The reason for giving corticotropin in the evening is to assure a good night's sleep and a start to the day free from stiffness. In the late afternoon, when the steroid output falls and stiffness begins to return, the patients are better able to cope with the situation by keeping on the move or taking aspirin. A further matter to consider is the measure used for assessing the degree of adrenal stimulation. The urinary assay of $17 \mathrm{KGS}$ and $17(\mathrm{OH}) \mathrm{CS}$ reflects quantitatively the adrenal output of cortisol (for a review of this subject see West, 1957), but is this all we need to know? Clinically, at least for most patients, this measure of adrenocortical activity correlates very well with the therapeutic effects, but theoretically it may not measure the physiologically-active hormone (or hormones) available to the tissues. In those patients who develop hypertension or fluid retention (in the absence of renal or cardiac disease), it may be that there is a qualitatively different adrenal secretion not reflected by this measure of cortisol metabolites. It will be of interest to measure the adrenal output of aldosterone, corticosterone, and 11-desoxycortisol of these patients.

\section{Effect upon Rheumatoid Arthritis}

There are three major questions to be asked of this study:

(1) Has the adrenal stimulation therapy proved superior to oral cortisone therapy and if so why?

(2) Do the advantages of this therapy outweigh the disadvantages?

(3) If it is concluded that the therapy has favourably affected the course of the disease is this finding of aetiological significance?

(1) Has the adrenal stimulation therapy proved superior to oral cortisone therapy, and if so why?

The answer to the first part of this question turns on the validity of the comparisons made between this study and the others referred to. It is generally agreed that the prognosis for early cases of rheumatoid arthritis is much better than that for cases of some years duration. This being so one would have expected this study group to have compared unfavourably with the M.R.C.-Nuffield Foundation aspirin-cortisone trial group (1955), since only six of the 42 patients began treatment with a disease duration of 3 to 9 months. With regard 
to the other groups used for comparison, the Tables show that the adrenal stimulation group started treatment with no advantage which could be revealed by erythrocyte sedimentation rate, haemoglobin level, strength of grip, or physical ability, yet ended with relative advantages in each characteristic. The most objective evidence of advance in the disease is to be found in the radiological appearance of bone erosions. Using this evidence for comparison, there can be no doubt that this group has fared much better than those treated with cortisone and aspirin. If one assumes that these latter treatments have not unfavourably affected the course of the disease, one is left with the conclusion that adrenal stimulation therapy has favourably affected the course of the disease-at least during the periods of observation. (It should be remembered that this study is concerned with severe cases of rheumatoid arthritis.) The possible reason why adrenal stimulation therapy is superior to aspirin will be referred to below. The reason why it is superior to oral corticosteroid therapy may be found in the essential differences between these two methods of giving adrenal hormone treatment. In one the adrenal is stimulated to increase its output of steroids which pass directly into the systemic circulation. In the other a single corticosteroid replaces the normal adrenal output and this corticosteroid must pass through the liver in high concentration before reaching the systemic circulation. The fact that oral corticosteroid therapy and adrenal stimulation therapy appear equally effective in the early weeks of treatment suggests that an adaptation may occur to the orallyadministered corticosteroid with the passage of time, but, unfortunately, changing from oral to intramuscular corticosteroid therapy does not improve the patient's state. It is a common experience to see severe rheumatoid arthritis patients after a year or more of oral corticosteroid therapy showing obvious signs of hypercortisonism, yet with their disease as disabling as when they started therapy. Our patients on adrenal stimulation therapy have not presented this picture. If their therapy had to be withdrawn it was for other reasons.

(2) Do the advantages of this therapy outweigh the disadvantages?

Records of erythrocyte sedimentation rate, strength of grip, and so on, provide evidence of improvement in the state of patients but give little clue to the difference the treatment has made to their lives. The response of most patients can be summed up in the words of a patient who had received aspirin in the M.R.C.-Nuffield aspirin-cortisone trial for 4 years. He began in the trial with no bony erosions but is now crippled beyond repair. Having just completed 6 months' adrenal stimulation therapy, he said: "Doctor, these injections are life to me". Do these advantages that the majority of patients have enjoyed outweigh the disadvantages? Most patients think nothing of the inconvenience occasioned by the need to give themselves daily injections and to collect $24-\mathrm{hr}$ specimens.

Of complications the major evil has been the allergenic nature of the corticotropin used. This has been the commonest cause of withdrawal and has been responsible for some alarming and dangerous anaphylactic reactions. The possibility that the repeated injections of foreign protein may add disease to disease cannot be excluded. These complications are not due to the essential element of the treatment, namely an increased production of adrenal hormones, and should disappear with the advent of purer corticotropins. The other complications fall into two categories. Those such as hypertension and fluid retention that are reversible and harmless if therapy is withdrawn, and those such as psychosis and congestive heart failure that can be avoided if the degree of adrenal stimulation is well controlled. With pure corticotropin and proper control of therapy there should be no deleterious effects to set against the benefits.

But what of the future? Severe rheumatoid arthritis that has already lasted for several years usually grumbles on for a very long time. Can adrenal stimulation therapy be continued indefinitely? Will the hypothalamicadenohypophyseal ACTH-producing mechanism return to normal after prolonged inactivity, and will normal function be adequate after years of living with a raised adrenocortical output of steroids? These questions remain to be answered. So far six patients have had continuous effective adrenal stimulation therapy for more than 3 years and are grateful for it. Patient 42, who is in her fifth year of treatment, remains in better health than she had been for many years before treatment began. For the 2 years before starting treatment she had to attend the eye department twice weekly for the treatment of iritis or corneal ulceration. She has not needed to return there since, though each evening when her injection is due her eyes begin to feel gritty.

(3) Have these findings any bearing on the aetiology of the disease?

It is commonly considered that the action of certain corticosteroids on rheumatoid arthritis is

.


merely that of non-specific anti-inflammatory agents. This demonstration that adrenal stimulation therapy does favourably affect the course of severe rheumatoid arthritis without at the same time producing any demonstrable effects upon the course of the everyday inflammatory responses, occasioned by bacterial, viral, and physical agents, should put an end to this unhelpful and rather thoughtless assumption. This is not the place to engage in speculation as to the aetiology of the disease, but one is tempted to suggest that there may be a breakdown in a particular enzymic process, perhaps an inherited defect in response to an ubiquitous environmental agent, that an increased local concentration of cortisol may reverse. One might expect the physical and emotional stress of severe rheumatoid arthritis to stimulate the adrenal cortex (via the hypothalamus and pituitary) and to raise the level of cortisol in the tissues naturally, but it does not do so (West, 1957). Is this in itself a defect?

The pattern of rheumatoid arthritis can vary so much that it is reasonable to assume that more than one agent is at work. The simplest concept is of local and humoral factors which may vary in relative importance from patient to patient. When the humoral factor is operative (? a low effective level of tissue cortisol) and the local factor not too gross, then adrenal stimulation therapy may reverse the defect.

\section{Other Effects of Adrenal Stimulation Therapy}

The adrenal cortex is the first of the endocrine glands to have been subjected to controlled stimulation for prolonged periods in man. The majority of the patients studied have started with a "normal" output of $17(\mathrm{OH}) \mathrm{CS}$, have had that output doubled for a prolonged period, and appear to have received nothing but benefit. This naturally leads to the question whether a person's "normal" adrenocortical output is in fact his optimum output. Before this problem can be adequately tackled we shall need more reliable corticotropin and more comprehensive assay procedures for measuring just what steroids the adrenal cortex is producing.

The part that the adrenocortical secretions play in the causation of hypertension remains obscure. The level of blood pressure in untreated rheumatoid arthritics bears no relation to their output of $17(\mathrm{OH}) \mathrm{CS}$ (unpublished findings), and as can be seen from Table $I$ the raising of the output of $17(\mathrm{OH}) \mathrm{CS}$ may or may not be associated with the production of hypertension. The question that these findings raise is whether the hypertension produced has resulted from a qualitatively abnormal secretion. As mentioned above, additional assay procedures are needed to answer this question-both for treated patients and in the case of Cushing's syndrome.

In the past, adrenocortical activity has been considered mainly in terms of gross deficiency and gross excess, with the Addisonian syndrome on the one hand, and on the other potassium depletion, sodium retention, protein catabolism, excessive fat deposition, osteoporosis, ulcerogenesis, and loss of response to infection. This is rather like considering the activity of insulin only in terms of hyper- and hypo-glycaemic coma. It is hoped that the findings of this study, in which electrolyte imbalance, protein catabolism, excessive fat deposition, osteoporosis, peptic ulceration, and lack of response to infection, have not accompanied increased adrenocortical activity, will promote more interest in physiological levels of adrenocortical activity.

\section{Summary}

An account is given of all the rheumatoid arthritic patients who have received adrenocortical stimulation therapy at this Centre during the past $4 \frac{1}{2}$ years. Records are presented of the clinical and laboratory findings in $\mathbf{4 2}$ patients given continuous therapy, measured by urinary steroid assays, for from 3 to 50 months (average $16 \mathrm{mths}$ ). This group includes 22 patients treated for from 12 to 50 months (average 25 mths).

The results of the therapy are compared with the published results of controlled therapeutic trials in the treatment of rheumatoid arthritis. The nature of the therapy and its control are described and discussed and some of the implications of the findings are commented upon.

The following conclusions are drawn:

(1) That adrenocortical stimulation therapy, providing a daily urinary output of from 20 to $30 \mathrm{mg}$. $17(\mathrm{OH}) \mathrm{CS}$, favourably affects the course of severe rheumatoid arthritis over prolonged periods in the majority of patients, and that in this respect it is superior to oral cortisone therapy.

(2) That the therapy described need not give rise to any serious side-effects or complications. That it does not, for instance, favour the development of peptic ulceration.

(3) That there is a wide range of adrenocortical activity between the clinically obvious extremes of Addison's disease and Cushing's syndrome, and that the effects of changes within this range warrant study in relation both to "normal" health and to disease states.

I wish to acknowledge a large measure of clinical help from Dr. G. R. Newns and to thank the nursing staff and the staff of the laboratories without whose help this study would not have been possible. 


\section{REFERENCES}

Appleby, J. I., Gibson, G., Norymberski, J. K., and Stubbs, R. D. (1955). Biochem. J., 60, 453.

Empire Rheumatism Council (1955). Annals of the Rheumatic Diseases, 14, 353.

Medical Research Council-Nuffield Foundation (Joint Committee) (1955). Brit. med. J., 2, 695. (1955). Ibid., 2 , 199.

Norymberski, J. K., Stubbs, R. D., and West, H. F. (1953). Lancet,

West, H. F. F. (1956). Annals of the Rheumatic Diseases, 15, 124. (1957). Ibid., 16, 173.

- and Newns, G. R. (1953). Lancet, 2, 1123.

(1955). Ibid., 1, 578.

Effets de stimulation surrénocorticale prolongée sur des malades atteints d'arthrite rhumatismale

\section{RÉSUMÉ}

On fait un compte-rendu de tous les malades atteints d'arthrite rhumatismale et traités par la stimulation surrénocorticale dans ce Centre durant les derniers quatre ans et demi. On présente les rapports des résultats cliniques et de laboratoire chez 42 malades soumis au traitement continu, et mesuré par leur excrétion urinaire des stéroïdes, pendant 3 à 50 mois (16 mois en moyenne). Ce groupe comprend 22 malades traités pendant 12 à 50 mois ( 25 mois en moyenne).

On compare les résultats de ce traitement avec les résultats publiés d'essais contrôlés. On décrit et discute la nature du traitement et ses méthodes de contrôle et on commente quelques-unes des implications de ces résultats. On tire les conclusions suivantes:

(1) Le traitement de stimulation surrénocorticale produisant une excretion urinaire quotidienne de 20 à $30 \mathrm{mg}$. de 17-hydroxycorticostéroïdes affecte favorablement le cours de l'arthrite rhumatismale sévère, sur des périodes prolongées et chez la majorité des malades, et est supérieur sur ce point, au traitement par cortisone buccale.

(2) Le traitement décrit ne provoque pas nécessairement d'effets secondaires sérieux ou de complications. Il ne favorise pas, par exemple, l'ulcération peptique.

(3) Il existe une large marge d'activité surrénocorticale entre les extrêmes cliniques évidents de la maladie d'Addison et du syndrome de Cushing et les effets des altérations à l'intérieur de cette marge méritent des études aussi bien du point de vue de la santé "normale" que de l'état morbide.

Efectos de estimulación suprarreno-cortical prolongada sobre enfermos con artritis reumatoide

\section{Sumario}

Se relata aquí todos los casos de artritis reumatoide tratados por estimulación suprarreno-cortical en este Centro durante los últimos cuatro años y medio. Se presentan datos clínicos y de laboratorio respecto a 42 enfermos, sometidos a una terapia continua, controlada por determinaciones de esteroides urinarios, durante 3 a 50 meses (un promedio de 16 meses). Este grupo incluye 22 enfermos tratados durante 12 a 50 meses (un promedio de 25 meses).

Se comparan los resultados de este tratamiento con los resultados publicados de ensayos terapéuticos controlados en esta enfermedad. Se describe y se discute la naturaleza y los métodos de control del tratamiento, y se anotan las implicaciones de los resultados. Se llega a las conclusiones siguientes:

(1) El tratamiento por estimulación suprarrenocortical produciendo una excreción urinaria diaria de 20 a $30 \mathrm{mg}$. de 17-hidroxocorticosteroides afecta favorablemente la evolución de la artritis reumatoide severa, durante períodos prolongados y en la mayoría de los enfermos, y es superior, desde este punto de vista, a la cortisona por vía oral.

(2) El tratamiento mencionado no provoca necesariamente efectos secundarios graves o complicaciones. Tampoco favorece, por ejemplo, la formación de úlceras pépticas.

(3) Hay un amplio margen de actividad suprarrenocortical entre los extremos clínicos obvios de la enfermedad de Addison y del síndrome de Cushing y los efectos de las alteraciones dentro de este margen merecen estudios ulteriores desde el punto de vista tanto de "normalidad" como de estado mórbido. 